\title{
Osteopontin expression and its possible functions in the aortic disorders and coronary artery disease
}

\author{
A expressão da osteopontina e as suas funções possíveis nas desordens aórticas e doença arterial \\ coronariana
}

Shi-Min YUAN ${ }^{1}$, Jun WANG ${ }^{2}$, Hai-Rong $\mathrm{HUANG}^{3}$, Hua $\mathrm{JING}^{4}$

RBCCV 44205-1264

\begin{abstract}
Background: Osteopontin (OPN) has been verified to be closely associated with oncogenesis and remodeling processes. But this cytokine was rarely assessed in the presence of aortopathies, especially acute aortic dissection. The aim of the present study was to evaluate the expressions of OPN by way of molecular biological approaches so as to offer a better understanding of the possible mechanisms of the aortopathies.

Methods: Consecutive patients with type A acute aortic dissection (20 patients), aortic aneurysm (nine patients) or coronary artery disease ( 21 patients) referred to this hospital for surgical operations were enrolled into this study. Blood samples of the surgical patients after systematic heparinization, and control fast morning blood samples drawn from 21 young healthy volunteers who had no evidence of any healthy problems were investigated for enzyme linked immunosorbent assay (ELISA). The surgical specimens of the aortic tissues collected from the surgical patients during the operations were obtained for quantitative realtime reverse transcription polymerase chain reaction (RT-PCR) for OPN mRNA, western blot assay for OPN protein, and for immunohistochemical staining of OPN. Ascending aortic tissues from the autopsies of the healthy individuals dying of accident were obtained as controls of immunohistochemistry.

Results: By quantitative RT-PCR, the expressions of OPN mRNA were all upregulated in all three surgical groups. The quantitative results did not reveal any intergroup
\end{abstract}

1. MD, PhD; Postdoctoral Researcher, Department of Cardiothoracic Surgery, Jinling Hospital, School of Clinical Medicine, Nanjing University, Nanjing, China.

2. MD, PhD; Department of Cardiothoracic Surgery, Jinling Hospital, School of Clinical Medicine, Nanjing University, Nanjing, China.

3. MD, MMed; Attending Surgeon, Department of Cardiothoracic Surgery, Jinling Hospital, School of Clinical Medicine, Nanjing University, Nanjing, China.

4. MD, Professor and Head, Department of Cardiothoracic Surgery, Jinling Hospital, School of Clinical Medicine, Nanjing University, Nanjing, China. differences. Western blot assay revealed that OPN was positive with similar intensities of expressions in all three surgical groups. Quantitative western blot analyses of OPN expressions did not show any significance between groups. The OPN expressions by ELISA in the aortic tissue were $3.09311 \pm 1.65737,3.40414 \pm 1.15095$, and $1.68243 \pm 0.31119$ $\mathrm{pg} / \mathrm{mg}$ protein in the aortic dissection, aortic aneurysm, and coronary artery disease groups, respectively. The OPN level of the patients with coronary artery disease was much lower than those with aortic dissection $(P=\mathbf{0 . 0 3 3})$ or with aortic aneurysm $(P=0.019)$. By unparametric tests, there were significant differences in the aortic OPN contents among aortic dissection, aortic aneurysm and coronary artery disease groups $(P<0.01)$. A significant direct correlation was present between plasma OPN concentration and the time interval from the onset to surgery of aortic dissection

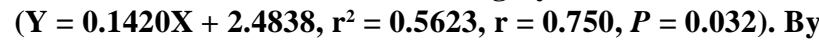
immunohistochemistry, OPN was expressed in the aortic cells: in the intima, it was weaker in all three surgical groups in comparison with the healthy control; in the media, it was weak in the aortic dissection, intense positive in aortic aneurysm, focal positive in the coronary artery disease, but evenly positive in the healthy control groups; and in the adventitia, it was positive in the aortic dissection, coronary artery disease and healthy control groups, but weak positive in the aortic aneurysm group.

Conclusion: These data may provide evidences that OPN may play a role in the pathogenesis of aortopathies including

Work done at Department of Cardiothoracic Surgery, Jinling Hospital, School of Clinical Medicine, Nanjing University, Nanjing, China.

Correspondence address:

Prof. Hua Jing, Department of Cardiothoracic Surgery, Jinling Hospital, School of Clinical Medicine, Nanjing University, Nanjing 210002, Jiangsu Province, China.

E-mail: dr.jing@163.com

Article received on November 13, 2010 Article accepted on March 1 $1^{\text {st }}, 2011$ 
aortic dissection, aortic aneurysm, and coronary artery disease. OPN might be of potential perspective as a clinically diagnostic tool in the evaluations of the complex remodeling process incorporating vascular injury and repair.

Descriptors: Angiogenesis Modulating Agents. Aorta. Cardiac Surgical Procedures. Extracellular Matrix Proteins. Osteopontin.

\section{Resumo}

Objetivos: A osteopontina (OPN) está estreitamente associada com os processos de oncogênese e remodelação. Entretanto, essa citocina era raramente avaliada na presença de aortopatias, especialmente na dissecção aórtica aguda. $O$ objetivo do presente estudo foi avaliar a expressão de OPN por meio de abordagens moleculares biológicas, de modo a oferecer uma melhor compreensão dos possíveis mecanismos das aortopatias.

Métodos: Pacientes consecutivos com um tipo de dissecção aguda da aorta (20 pacientes), aneurisma da aorta (nove pacientes) ou doença arterial coronária ( 21 pacientes) foram incluídos neste estudo. As amostras de sangue depois da heparinização sistemática e de 21 voluntários jovens e saudáveis não apontaram nenhuma evidência de qualquer problema ao serem investigados por ensaio imunoenzimático (ELISA). Os espécimes cirúrgicos dos tecidos aórtica coletados dos pacientes durante as operações foram obtidos para a reação de transcrição reversa quantitativa em tempo real em cadeia da polimerase (RT-PCR) para OPN mRNA, técnica de Western blot para a proteína OPN, e imunohistoquímica de OPN. Amostras da aorta de indivíduos saudáveis que morreram de acidente foram obtidos para controle imunohistoquímico.

Resultados: Com uso do RT-PCR quantitativo, as expressões de OPN mRNA foram suprarreguladas em todos os três grupos cirúrgicos. Os resultados quantitativos não revelaram quaisquer diferenças intergrupais. Western blot

\section{INTRODUCTION}

Osteopontin (OPN) is a $34 \mathrm{kDa}$ extracellular matrix protein, originally identified as a major component of the non-collagenous organic bone matrix. It has been demonstrated that OPN may be present in a wide range of normal adult tissues including the smooth muscle, endothelial cells, bone, placenta, brain, and kidney, and body fluids [1]. OPN mediates cell migration, adhesion, and survival in many cell types, and also functions as a Th1 cytokine, promotes cell-mediated immune responses, and plays a role in chronic inflammatory and autoimmune diseases [2], hence many diseases, such as Crohn's disease, cancer, autoimmune disease and obesity, characterized by chronic inflammation may have an elevated plasma OPN level [3].

In conditions with malignancy, sepsis, renal calculus, revelou que OPN foi positiva com intensidade semelhante de expressões em todos os três grupos. As análises quantitativas Western blot de expressões OPN não apresentaram significâncias entre os grupos. As expressões OPN medidas pelo teste ELISA no tecido aórtico foram $3,09311 \pm 1,65737,3,40414 \pm 1,15095$ e $1,68243 \pm 0,31119$ pg/ mg de proteína na dissecção de aorta, aneurisma da aorta, e grupos de doença arterial coronariana, respectivamente. $O$ nível de OPN dos pacientes com doença arterial coronariana foi muito menor do que aqueles com dissecção aórtica $(P=$ $0,033)$ ou com aneurisma da aorta $(P=0,019)$. Testes nãoparamétricos apontaram diferenças significativas nos teores de aorta OPN entre dissecção aórtica, aneurisma da aorta e grupos com doença arterial coronariana $(P<0,01)$. Uma correlação direta significativa estava presente entre a concentração plasmática OPN e o intervalo de tempo entre 0 início da cirurgia de dissecção de aorta $(Y=2,4838+$ $\left.0,1420 X, r^{2}=0,5623, r=0,750, P=0,032\right)$. Pela imunohistoquímica, a OPN foi expressa em células aórticas: na íntima, foi fraca em todos os três grupos cirúrgicos em comparação ao grupo saudável; na média, era fraca na dissecção aórtica, positiva intensa no aneurisma de aorta, focal positivo na doença arterial coronariana, mas igualmente positiva no grupo controle; e na adventícia, positiva para a dissecção da aorta, doença arterial coronariana e grupos de controle saudáveis, mas fraca positiva no grupo de aneurisma da aorta.

Conclusão: Estes dados fornecem evidências de que a OPN pode desempenhar um papel na patogênese da aortopatias, incluindo dissecção aórtica, aneurisma da aorta $R$ e doença arterial coronariana. OPN tem perspectiva potencial como ferramenta de diagnóstico clínico nas avaliações do processo de remodelação complexa, incluindo lesão vascular e de reparação.

Descritores: Agentes Moduladores da Angiogênese. Aorta. Procedimentos Cirúrgicos Cardíacos. Proteínas da Matriz Extracelular. Osteopontina.

multiple sclerosis, and vascular diseases such as diabetic retinopathy and aneurysm, OPN was also noted to be upregulated [4]. The OPN mRNA expressions could be enhanced in distal tubule of renal calculus [5], Kupffer cells and hepatic macrophages and stellate cells in rat liver after carbon tetrachloride intoxication [6]. It was illustrated that OPN mRNA was much highly expressed in malignancies than in benign lesions, and the expression was closely related to the differentiation, invasion, patient's age and GTM stage (also termed as Enneking staging system based on tumor grade, site and metastasis) but not patients' gender and tumor size [7]. Besides, OPN expression was directly correlated with the expression of CD44s proteins [7].

In coronary patients, the overexpressions of OPN were typically related to the presence and extent of atherosclerotic plaques and calcification lesions in the aorta [8,9]. OPN levels were significantly more increased in patients with 
peripheral artery disease than those without, and they were speculated to be due to the stimulation by angiotension II [10]. Acute aortic syndrome including aortic dissection, aortic aneurysm and penetrating atherosclerotic ulceration are increasingly inspected by the popularly used nontraumatic instruments including echocardiography, computed tomography, and magnetic resonance imaging [11]. However, the mechanisms responsible for the development of the aortopathies still remain undetermined. Even though studies have revealed the potential effects of OPN in angiogenesis, no systemic study was found in the literature regarding OPN expressions and biological functions in the vascular remodeling of aortic disorders. The aim of the present study was to detect OPN expressions in the aortic wall and plasma of patients with aortic dissection, aortic aneurysm and coronary artery disease.

\section{METHODS}

\section{Patients and sampling}

From 2008 to present, consecutive surgical patients for type Aacute aortic dissection (20 patients), aortic aneurysm (nine patients) or coronary artery disease (21 patients) who had blood and/or aortic tissue samples available were selected randomly into this study, whilst Marfan patients were excluded. Blood samples $(4 \mathrm{ml})$ were obtained from the right radial arterial indwelling catheter of the surgical patients after systemic heparinization prior to the start of cardiopulmonary bypass. Twenty-one young healthy volunteers without underlying health issues who donated forearm venous blood samples $(4 \mathrm{ml})$ were taken as controls for plasma enzyme linked immunosorbent assay (ELISA).

Blood was centrifugated at $3000 \mathrm{rpm}$ for $5 \mathrm{~min}$, and the plasma was taken stored at $-80^{\circ} \mathrm{C}$ until detection. The surgical specimens of large aortic tissues were obtained immediately after they were severed in the operations of the replacement of the aorta in the patients with aortic dissection or aortic aneurysm. The aortic tissue of each patient was divided into two parts: one was stored at $-80^{\circ} \mathrm{C}$, which would be thawed for mRNA or for protein preparations with quantitative real-time reverse transcription polymerase chain reaction (RT-PCR) or western blot, or made into supernatant for ELISA assay until detection; and the other was fixed in $10 \%$ formaldehyde solution for immunohistochemical examinations.

The aortic tissues $0.2 \sim 0.4 \mathrm{~cm}$ in size taken from the punch holes of the proximal anastomosis on the anterior wall of the ascending aorta in patients receiving coronary artery bypass were collected. These small aortic tissues were for either biomolecular or immunohistochemical studies. Ascending aortic tissues from the autopsies of the healthy individuals dying of accident were obtained as controls of immunohistochemistry. The demographic features of the studying subjects were listed in Table 1. This study was approved by the institutional ethical committee, and was conducted following the guidelines of the Declaration of

Table 1. Demographic data.

\begin{tabular}{|c|c|c|c|c|}
\hline Variables & Aortic Dissection & Aortic Aneurysm & Coronary Artery Disease & Healthy Control \\
\hline Case, $\mathrm{n}$ & 20 & 9 & 21 & 8 (tissue), 21 (plasma) \\
\hline Female gender & $2 / 20$ & $3 / 9$ & $2 / 21$ & 3/8 (tissue), 2/21 (plasma) \\
\hline Age, year & $53.78 \pm 9.67$ & $46.20 \pm 11.16$ & $60.33 \pm 4.87$ & $\begin{array}{l}25.42 \pm 20.03 \text { (tissue) } \\
28.17 \pm 2.61 \text { (plasma) }\end{array}$ \\
\hline Symptom, n & $\begin{array}{c}\text { Chest pain (18), chest } \\
\text { distress (2) }\end{array}$ & $\begin{array}{l}\text { Chest pain (3), chest distress (2), } \\
\text { palpitation (1), laryngeal } \\
\text { discomfort (1), abdominal pain } \\
\text { (1), asymptomatic (1) }\end{array}$ & Chest pain (21) & - \\
\hline Operation, $\mathrm{n}$ & $\begin{array}{l}\text { Replacement of the } \\
\text { aorta (ascending/arch/ } \\
\text { descending) with/ } \\
\text { without aortic valve } \\
\text { replacement/stent graft } \\
\text { deployment (20) }\end{array}$ & $\begin{array}{l}\text { Replacement of the ascending } \\
\text { aorta (3), Replacement of the } \\
\text { ascending aorta and aortic valve } \\
\text { (2), aortic arch replacement (1), } \\
\text { thoracic and abdominal aorta } \\
\text { replacement (1)descending aorta } \\
\text { replacement (1), Bentall } \\
\text { procedure (1) }\end{array}$ & $\begin{array}{l}\text { Off-pump coronary artery } \\
\text { bypass (15), coronary } \\
\text { artery bypass grafting (5), } \\
\text { beating heart coronary } \\
\text { revascularization }(1)\end{array}$ & - \\
\hline Disease course, month & $0.13 \pm 1.66$ & $62.82 \pm 168.61$ & $41.88 \pm 49.74$ & - \\
\hline Survival, \% & 100 & 85 & 100 & - \\
\hline
\end{tabular}


Helsinki. Informed consent was obtained from each patient. Quantitative RT-PCR RNA samples were treated with DNase I before reverse transcription processing to remove genomic DNA contamination. A total of $2-5 \mu \mathrm{g}$ of RNA from each sample was reverse transcribed into cDNA using the SuperScript ${ }^{\mathrm{TM}}$ III first-strand synthesis system (Invitrogen) according to the manufacturer's suggested protocol. Quantitative RT-PCR reactions were designed and prepared with a KeyGen reaction kit in a final volume of $20 \mu \mathrm{l}$ containing $1 \mu \mathrm{l}$ of reverse-transcribed total RNA, $2 \mu \mathrm{l}$ of primers, and $10 \mu \mathrm{l}$ of KeyGen Real-time PCR Master Mix (SYBR Green) (KeyGEN Bio, Nanjing, China). PCR reactions were carried out in capillaries in a DA7600 LightCycler instrument (Da An Gene Co., Ltd. of Sun Yatsen University, Guangzhou, Guangdong, China) and were cycled 40 times. The primers of OPN were designed and synthesized by KeyGEN Bio, Nanjing, China as the following: sense 5' - TCACCAGTCTGATGAGTCTCAC3' and antisense 5' - CAGGTCTGCGAAACTTCTTAGAT3', along with the internal control GAPDH: sense 5'GGAAGGTGAAGGTCGGAGTCA-3'; and antisense 5'GTCATTGATGGCAACAATATCCACT-3'. The thermal cycling conditions consisted of a pre-incubation for $5 \mathrm{~min}$ at $95^{\circ} \mathrm{C}$, followed by 40 cycles of denaturation for $15 \mathrm{~s}$ at $95^{\circ} \mathrm{C}$, annealing for $30 \mathrm{~s}$ at $60^{\circ} \mathrm{C}$ and extension for $30 \mathrm{~s}$ at $72^{\circ} \mathrm{C}$, and a final extension for $10 \mathrm{~min}$ at $72^{\circ} \mathrm{C}$. All experiments were done in triplicate to verify the results. The relative expression of OPN mRNA to GAPDH mRNA was calculated.

\section{ELISA}

The expression of OPN was determined with commercially available ELISA kit (Human OPN ELISA kit, Senxiong Technology Industry Co., Ltd., Shanghai, China) for the detection of human plasma and human tissue homogenates by sandwich ELISA according to specialized procedures described in the instructions for users of the product. The sensitivity of the kit was minimally $4 \mathrm{ng} / \mathrm{ml}$ for human OPN detection, and the intra-assay and inter-assay coefficient of variation were $<10 \%$ and $<15 \%$, respectively.

\section{Western blot}

Protein extracts $(10 \mathrm{mg})$ of the aortic tissue were denatured in sodium dodecyl sulfate (SDS)-polyacrylamide gel electrophoresis (PAGE) loading buffer and separated by $12 \%$ SDS-PAGE. Proteins were transferred to a microporous polyvinylidene difluoridemembrane (PVDF) membrane using an electroblotting apparatus and incubated for $1 \mathrm{~h}$ at room temperature with $0.5 \%$ bovine serum albumin. Membranes were stained with Poinceau $S$ dye, to check for equal loading and homogeneous transfer. The primary OPN antibody (Santa Cruz Biotechnology, Inc., Heidelberg, Germany) was utilized. Filters were washed and developed using an enhanced chemiluminescence system (ECL, Amersham Life Science). The optical densities were obtained by scanning densitometry, after normalization for nuclear or cytoplasmatic housekeeping gene product ( $\beta$ actin).

\section{Immonuhistochemistry}

The aortic tissue samples were fixed in $10 \%$ methanal solution in $1 \mathrm{~cm}^{3}$ blocks, embedded in paraffin wax, processed routinely and stained with hematoxylin-eosin on $4 \mu \mathrm{m}$ sections. Immunohistochemical staining of OPN was performed by using Envision method. A primary antibody OPN (AKm2A1) sc-21742 (1:100) purchased from Santa Cruz Biotechnology, Inc., CA, USA, was used.

\section{Statistics}

Data were expressed as mean \pm standard deviation. Oneway ANOVA analysis of variance and unparametric rank sum test were used for inter-group analyses. A two-tailed $P$ value less than 0.05 was considered significant. Linear correlations were evaluated between independent and dependent variables: $0.3 \leq|\mathrm{r}|<0.5$ was taken as low correlative, $0.5 \leq|\mathrm{r}|<0.8$ as median correlative, and $|\mathrm{r}| \geq 0.8$ as high correlative.

\section{RESULTS}

\section{Quantitative RT-PCR}

The melting curves showed the rate of change of the relative fluorescence units (RFU) with time (T) (-d(RFU)/ $\mathrm{dT}$ ) on the $\mathrm{Y}$-axis versus the temperature on the $\mathrm{X}$-axis, and a single peak at the melting temperature (Tm) of $85.1^{\circ} \mathrm{C}$ for the samples (Figure 1) and $84^{\circ} \mathrm{C}$ for the control, respectively. The expressions of OPN mRNA were all upregulated in all three groups. The quantitative results did not reveal any intergroup differences (Figure 2).

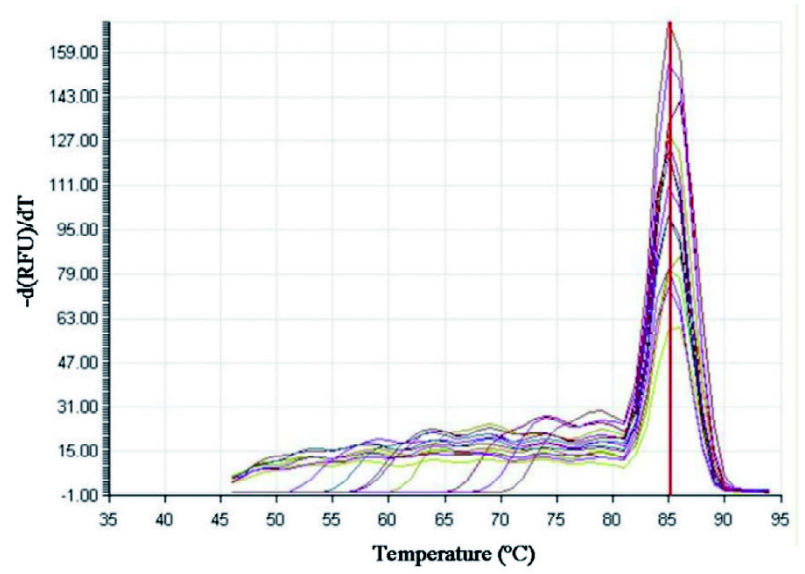

Fig. 1 - The melting curves indicated a single peak with a melting temperature (Tm) of $85.1^{\circ} \mathrm{C}$ for the samples 


\section{Western blot}

Western blot assay revealed that OPN was positive with similar intensities of expressions in all three groups (Figure 3 ). By comparing the positive total and positive net grayscales between OPN and the internal control B-actin, no intergroup significances were noted in such relative values (Figure 4).

\section{ELISA}

By unpaired t-test, The OPN expressions in the aortic tissue were $3.09311 \pm 1.65737,3.40414 \pm 1.15095$, and 1.68243 $\pm 0.31119 \mathrm{pg} / \mathrm{mg}$ protein in aortic dissection, aortic aneurysm, and coronary artery disease groups,

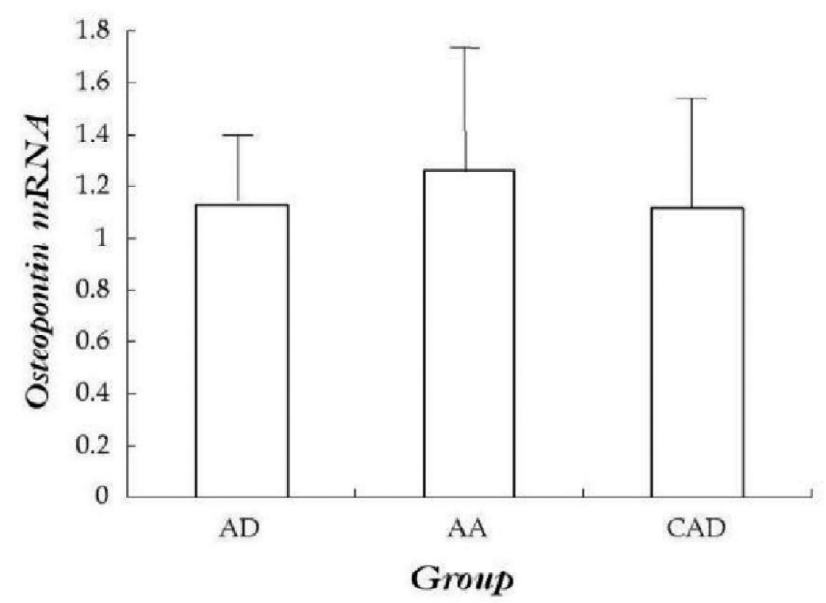

Fig. 2 - Quantitative real-time RT-PCR of osteopontin $m R N A$. $P=$ 0.318 for $A D$ vs. $A A, P=0.393$ for $A D$ vs. $C A D$, and $P=0.947$ for $A A$ vs. CAD. AA: aortic aneurysm; $A D$ : aortic dissection; $C A D$ : coronary artery disease

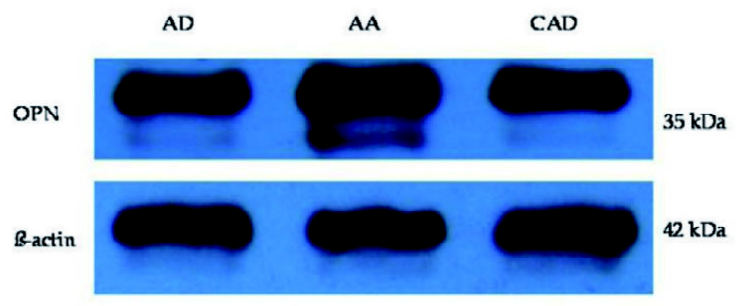

Fig. 3 - Western blot assay of the expressions of osteopontin protein. $A D$ : aortic dissection; $A A$ : aortic aneurysm; $C A D$ : coronary artery disease respectively. The OPN level of the coronary artery disease group was much lower than that of the aortic dissection $(P$ $=0.033)$ or the aortic aneurysm group $(P=0.019)$ (Figure 5). Plasma OPN concentrations were 3.18850 $\pm 1.24955,2.63643$ $\pm 2.68847,3.06726 \pm 6.36880,2.38476 \pm 2.30452 \mathrm{pg} / \mathrm{mL}$ in aortic dissection, aortic aneurysm, coronary artery disease, and healthly control, respectively (Figure 6). No significant differences were noted among them.

By rank sum test, there was no significant differences in the plasma OPN values among the four groups $(P>0.05)$, but there were significant differences in the aortic tissue OPN contents among aortic dissection, aortic aneurysm and coronary artery disease groups $(P<0.01)$.
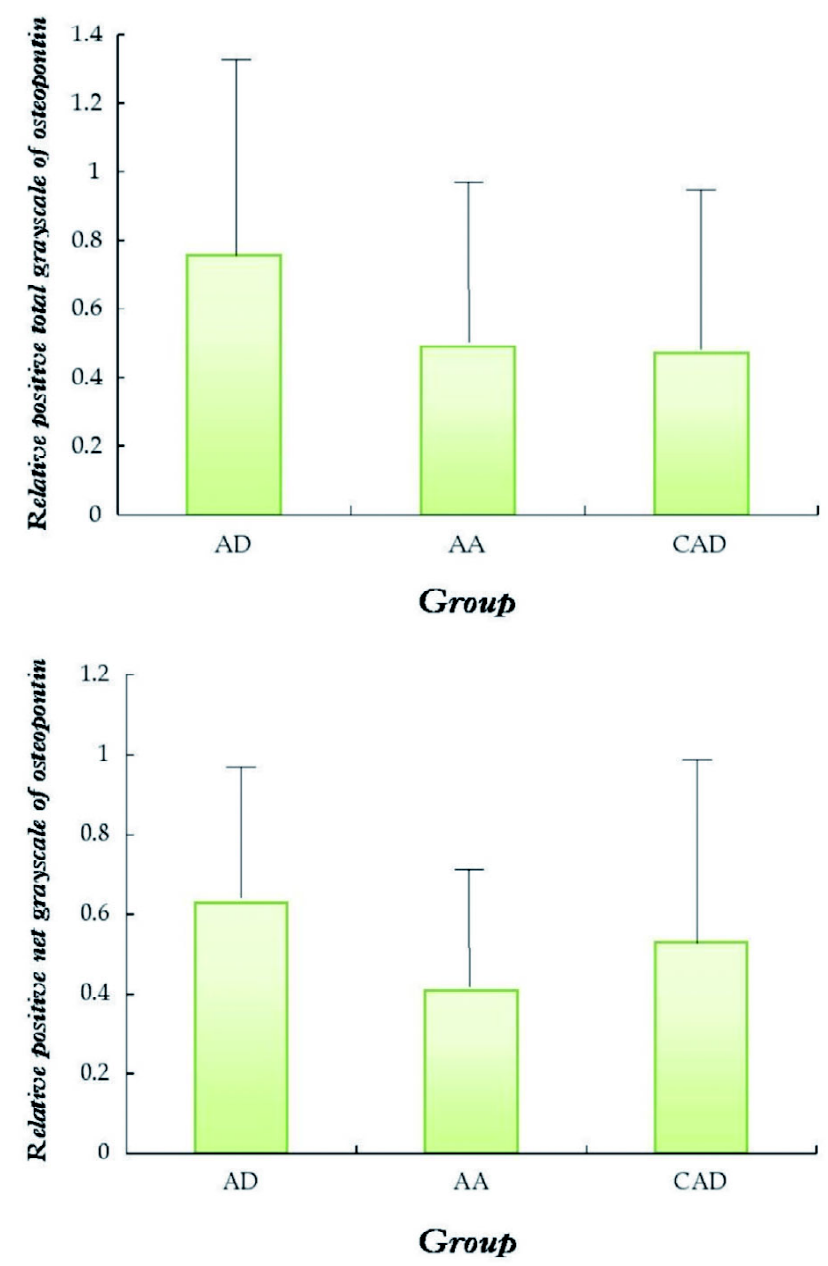

Fig. 4 - Relative grayscales of osteopontin by quantitative Western blot: (A) positive total grayscale: $P=0.229$ for $A D$ vs. $A A, P=$ 0.948 for $A D$ vs. $C A D$, and $P=0.240$ for $A A$ vs. $C A D$, and $(B)$ positive net grayscale: $P=0.151$ for $A D$ vs. $A A, P=0.519$ for $A D$ vs. $C A D$, and $P=0.554$ for $A A$ vs. $C A D$. $A A$ : aortic aneurysm; $A D$ : aortic dissection; $C A D$ : coronary artery disease 


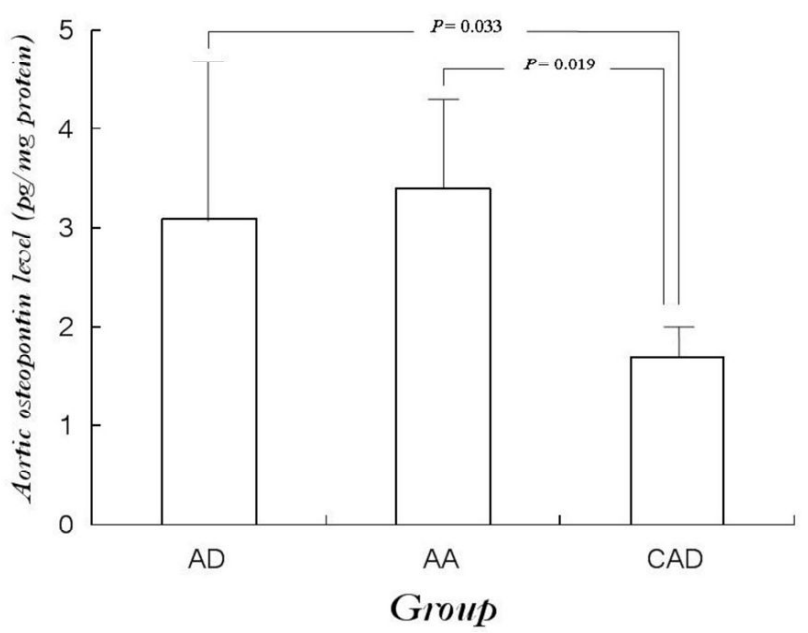

Fig. 5 - The osteopontin values in the aortic tissue detected by ELISA. $P=0.989$ for $A D$ vs. $A A, P=0.033$ for $A D v s$. $C A D$, and $P=0.019$ for $A A$ vs. CAD. AA: aortic aneurysm; $A D$ : aortic dissection; $C A D$ : coronary artery disease

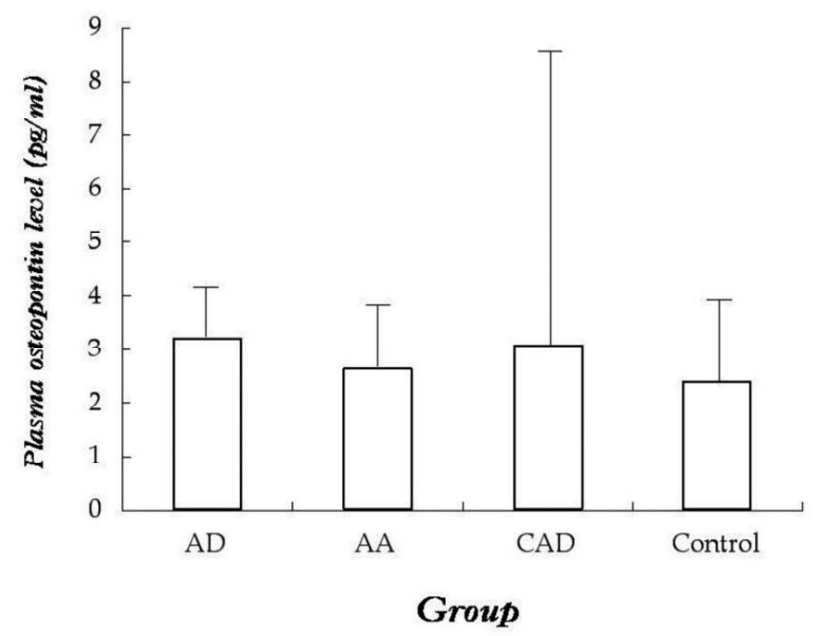

Fig. 6 - Plasma osteopontin concentrations detected by ELISA. $P=$ 0.602 for $A D$ vs. $A A, P=0.863$ for $A D$ vs. $C A D, P=0.812$ for $A D$ vs. healthy control, $P=0.958$ for $A A$ vs. $C A D, P=0.361$ for $A D$ vs. healthy control, and $P=0.649$ for $C A D$ vs. healthy control. $A A$ : aortic aneurysm; $A D$ : aortic dissection; $C A D$ : coronary artery disease

In the patients with aortic dissection, no correlation between aortic OPN level and time interval from the onset of aortic dissection to surgery $\left(\mathrm{Y}=0.0272 \mathrm{X}+2.9638, \mathrm{r}^{2}=\right.$ $0.0166, \mathrm{r}=0.129, P=0.661$ ) (Figure 7). However, a significant direct correlation was noted between plasma OPN concentration and the time interval from the onset to surgery $\left(\mathrm{Y}=0.1420 \mathrm{X}+2.4838, \mathrm{r}^{2}=0.5623, \mathrm{r}=0.750, P=0.032\right)$ (Figure 8). Neither aortic OPN level nor plasma OPN concentration correlated with the maximal size of the aorta (aortic OPN: $\mathrm{Y}=-0.1147 \mathrm{X}+3.5054, \mathrm{r}^{2}=0.0440, \mathrm{r}=0.210, P=$ 0.472; plasma OPN: $\mathrm{Y}=-0.2691 \mathrm{X}+5.0028, \mathrm{r}^{2}=0.1159, \mathrm{r}=$ $0.340, P=0.509)$.

\section{Immunohistochemistry}

OPN was expressed in the aortic cells. In the aortic intima, there was significant structural disruption in patients with aortic dissection, aortic aneurysm or coronary heart disease, associated with decreased expressions of OPN in comparison to healthy control. The intense of the expressions in a descending order was healthy control > coronary heart disease $>$ aortic aneurysm $>$ aortic dissection (Figure 9).

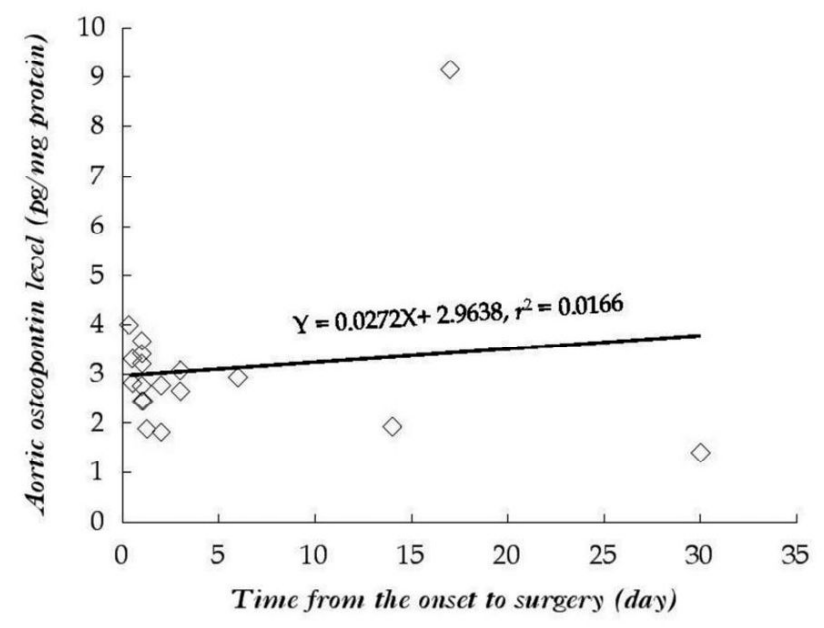

Fig. 7 - Correlation between osteopontin concentration in the aortic tissue and time interval from the onset to surgery in the patients with aortic dissection

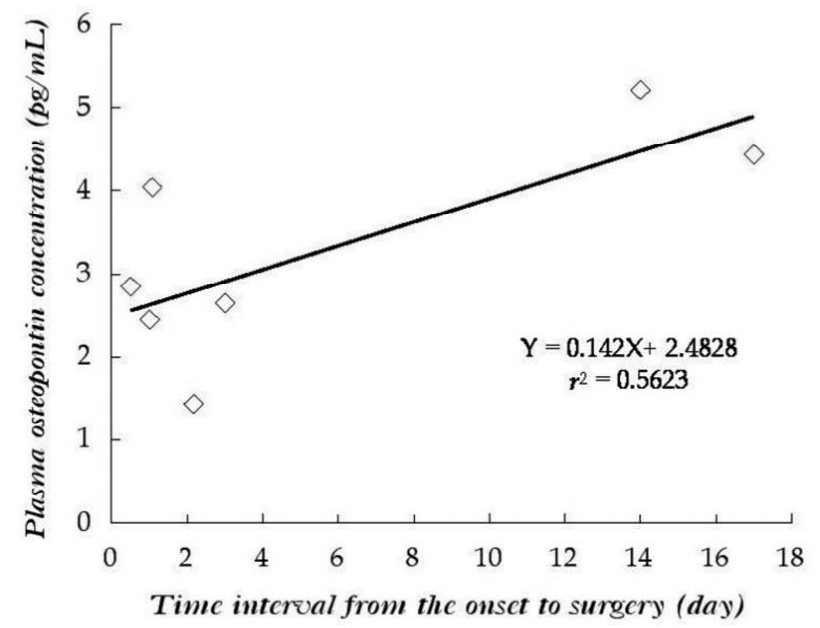

Fig. 8 - Correlation between plasma osteopontin concentration and time interval from the onset to surgery in the patients with aortic dissection 


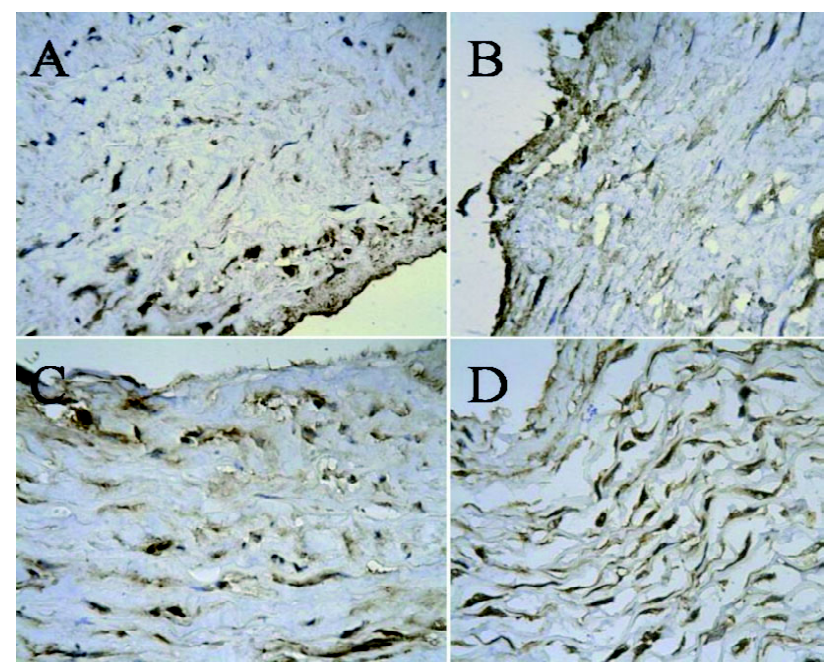

Fig. 9 - In the aortic intima, there was significant structural disruption in patients with aortic dissection $(A)$, aortic aneurysm (B) or coronary heart disease $(C)$, associated with decreased expressions of osteopontin in comparison to healthy control (D). The intense of the expressions in a descending order was healthy control > coronary heart disease > aortic aneurysm > aortic dissection. Envision $\times 400$

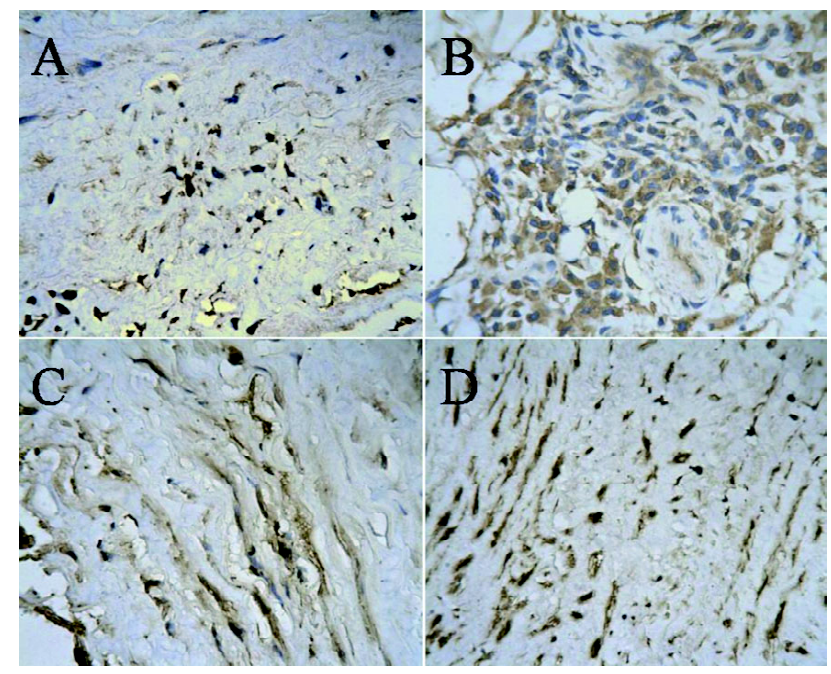

Fig. 10 - In the aortic media, the expression of osteopontin was weak in the aortic dissection $(A)$, intense positive in aortic aneurysm $(B)$, focal positive in the coronary artery disease $(C)$, but evenly positive in healthy control $(D)$. The intense of the expressions in a descending order was aortic aneurysm > healthy control > coronary heart disease > aortic dissection. Envision $\times 400$

In the aortic media, the expression of OPN was weak in the aortic dissection, intense positive in aortic aneurysm, focal positive in the coronary artery disease, but evenly positive in healthy control groups. The intense of the expressions in a descending order was aortic aneurysm $>$ healthy control > coronary heart disease $>$ aortic dissection (Figure 10).

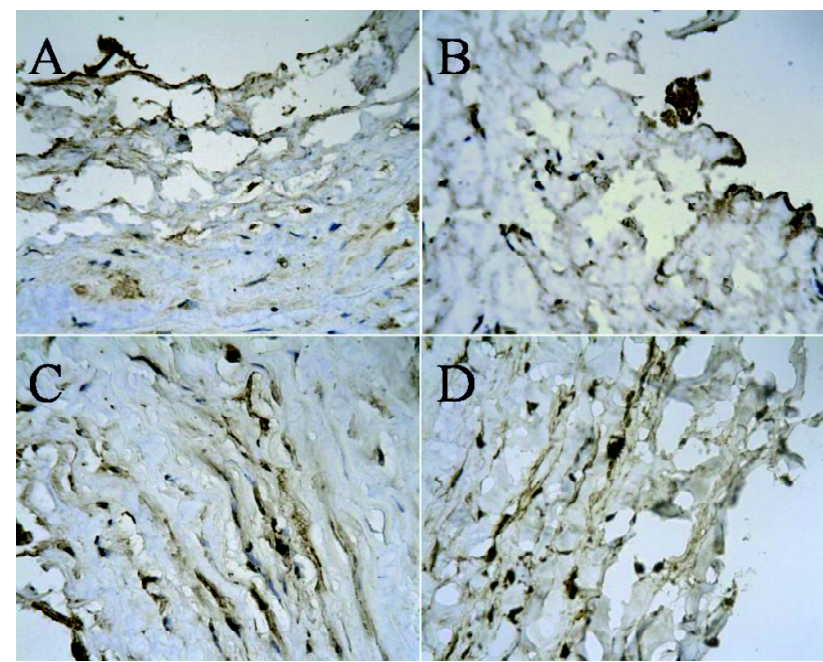

Fig. 11 - In the adventitia, the expressions of osteopontin was positive in the aortic dissection $(A)$, coronary artery disease $(C)$ and healthy control $(D)$ groups, while it was weak positive in the aortic aneurysm (B) group. Envision $\times 400$

In the adventitia, the expressions of OPN were positive in the aortic dissection, coronary artery disease and healthy control groups, while it was weak positive in the aortic aneurysm group (Figure 11).

\section{DISCUSSION}

Normal vessels expressed low levels of OPN [12]. Vascular damage due to mechanical injury induced by pressure or volume loads [13], or hypoxia [14], or intervened with angiotension II [15], was the initially proposed mechanism that may stimulate OPN expressions. Subsequently, studies revealed that OPN may regulate extracellular matrix remodeling by inhibiting interleukin-1ßstimulated increases in the activities of matrix metalloproteinases 2 and 9 and expression in adult rat cardiac fibroblasts [16]. Injury-induced OPN overexpression may induce medial thickening and neointimal formation, associated with smooth muscle cell proliferation, migration, and production of matrix metalloproteinases.

These changes suggested that OPN may modulate proliferation, migration and accumulation of smooth muscle and endothelial cells [17]. OPN overexpression in atherosclerotic plaques in human and animal models revealed the solid links with macrophages and foam cells [18]. OPN has been evidenced to be of dual functional properties: OPN may reflect the vascular damage extent induced by for example angioplasty maneuver on the one hand [19], and OPN overexpression may promote vascular remodeling and inhibit vascular dilation tendency, which was more likely to be proved by an association between OPN deficiency and weakening fibrotic contractility [20]. 
However, the biological function of OPN in the vessel walls in the condition of aortic dissection and aortic aneurysm is still not yet well understood [17].

Golledge et al. [21] found that the OPN levels of the aorta were correlated with the diameter of the aorta, with the OPN level of the small abdominal aortic aneurysm being twice of that of the other two groups. An elevated OPN expression of the abdominal aortic aneurysm was also proved by western blot assay.

The present study revealed upregulated OPN in the context of aortopathies in the local tissues other than in the plasma. In comparison to the coronary artery disease and (or) healthy control groups, OPN was enhanced in both aortic dissection and aortic aneurysm patients, while less overexpressed in the patients with aortic dissection than those with aortic aneurysm subject to western blot despite the lack of statistical significances.

It has been reported that the plasma OPN levels were higher in coronary artery disease than in control $(616 \pm$ $308 \mathrm{ng} / \mathrm{ml}, 443 \pm 237 \mathrm{ng} / \mathrm{ml}, P<0.001)$, and the OPN values were increased with the number of $>50 \%$ stenosed coronary arteries. Furthermore, the plasma OPN concentrations were correlated with the number of $>50 \%$ and $>25 \%$ stenosed, and the number of calcified coronary segments [22]. Plasma OPN concentrations may be significantly higher in coronary patients with restenosis after percutaneous coronary interventions than in those without restenosis or those without a history of percutaneous coronary interventions [23]. In patients with abdominal aortic aneurysm, serum OPN level was much higher than in those without, and it increased with progression of the disease, rather than in relation to the size of the aneurysm [21].

However, serum OPN in terms of its sensitivity and specificity may be influenced by underlying disease status/ stage and appropriate therapy [1]. In other words, an elevated OPN in the serum does not necessarily represent an increase in the local tissue, as the determination of the circulating OPN may rely on the types of antibodies as well as the underlying discerning locations [20]. In rat models of aortic and carotid balloon angioplasty, the expressions of OPN increased with time following damage of the arterial smooth muscle cells [24,25]. This was in an agreement with the direct linear correlation between the plasma OPN value and the time interval from onset of aortic dissection to surgery in our study. However, we did not notice a close relation between the OPN levels and the diameter of the aorta in the aortic dissection group.

The aorta expressed OPN mRNA in both transgenic and non-transgenic mice verified by northern blot [17]. In animal arterial injury model, the OPN mRNA expressions of smooth muscle cells of the neointima were significantly elevated [24]. OPN mRNA and protein expressions were increased in the synthetic phase of smooth muscle cells [26], indicating a phenotype transition of smooth muscle cells from the contractile to the synthetic [12]. OPN mRNA levels were temporally and spatially related to the active endothelial proliferation and migration, and the study in the rat model showed that the maximal expressions were present at the rim of the damage 8 hours to 2 weeks after balloon catheter injury to the carotid artery and aorta, and were decreased to the uninjured level at 6 weeks [27]. Therefore, aortic tissues with the pathological process of dissection may have a disregulated synthetic smooth muscle cells with less OPN mRNA expressions as shown in this study.

Immunohistochemistry demonstrated a strong staining of OPN in the lesions of ApoE/LDL receptor-deficient (AL) mice; whereas it was absent in ApoE/LDL receptor/OPN triple knockout (ALO) mice as well as in the media of ApoE/ LDL receptor-deficient (AL) mice [28]. The medial layers of the carotid arteries of streptozotocin-induced diabetic rats and the forearm arteries of diabetic patients stained positively for OPN antibodies, whereas the staining from arteries of control rats and nondiabetic patients was negative [29]. Moreover, OPN levels may significantly increase in patients with peripheral vascular disease than those without [10]. In the present study, the immunohistochemical results illustrated that OPN was hardly expressed in the intima and media of the aorta in patients with aortic dissection, but more intense in the aortic media of the patients with the aortic aneurysm, indicating a disruptive change in the aorta of aortic dissection but a proliferative change in aortic aneurysm.

\section{CONCLUSION}

In conclusion, in the cohort observed we found an upregulation of OPN in the patients with aortic dissection, aortic aneurysm, and coronary artery disease compared with healthy individuals. Considering the moderate direct correlation and the time interval from the onset to surgery $(r=0.750)$, in addition to a significant difference between plasma concentration of OPN in aortic dissection patients, the roles of OPN in the pathogenesis of the aortic or coronary artery diseases might be evidenced. These data may provide evidences that upregulation of OPN may play a role in the pathogenesis of aortopathies including aortic dissection, aortic aneurysm, and coronary artery disease. OPN might be of potential perspective as a clinically diagnostic tool for the evaluations of the complex remodeling process incorporating vascular injury and repair. Further investigations on OPN expression in large population of aortic or coronary patients and control aortic tissues from heart transplant donors would be necessary for more precise results. 


\section{REFERENCES}

1. Meenakshisundaram R, Chandra S, Thirumalaikolundusubramanian P. Osteopontin and its clinical significance. Indian J Pathol Microbiol. 2009;52(3):459.

2. Lund SA, Giachelli CM, Scatena M. The role of osteopontin in inflammatory processes. J Cell Commun Signal. 2009;3(34):311-22.

3. Agnholt J, Kelsen J, Schack L, Hvas CL, Dahlerup JF, Sørensen ES. Osteopontin, a protein with cytokine-like properties, is associated with inflammation in Crohn's disease. Scand J Immunol. 2007;65(5):453-60.

4. Denhardt DT, Mistretta D, Chambers AF, Krishna S, Porter JF, Raghuram S, et al. Transcriptional regulation of osteopontin and the metastatic phenotype: evidence for a Ras-activated enhancer in the human OPN promoter. Clin Exp Metastasis. 2003;20(1):77-84.

5. Umekawa T, Kohri K, Kurita T, Hirota S, Nomura S, Kitamura Y. Expression of osteopontin messenger RNA in the rat kidney on experimental model of renal stone. Biochem Mol Biol Int. 1995;35(1):223-30.

6. Kawashima R, Mochida S, Matsui A, YouLuTuZ Y, Ishikawa $\mathrm{K}$, Toshima K, et al. Expression of osteopontin in Kupffer cells and hepatic macrophages and Stellate cells in rat liver after carbon tetrachloride intoxication: a possible factor for macrophage migration into hepatic necrotic areas. Biochem Biophys Res Commun. 1999;256(3):527-31.

7. Beckebaum S, Chen X, Sotiropoulos GC, Radtke A, Daoudaki M, Baba HA, et al. Role of osteopontin and CD44s expression for patients with hepatocellular carcinoma undergoing liver transplantation or resection. Transplant Proc. 2008;40(9):3182-4.

8. O'Brien ER, Garvin MR, Stewart DK, Hinohara T, Simpson JB, Schwartz SM, et al. Osteopontin is synthesized by macrophage, smooth muscle, and endothelial cells in primary and restenotic human coronary atherosclerotic plaques. Arterioscler Thromb. 1994;14(10):1648-56.

9. Ikeda T, Shirasawa T, Esaki Y, Yoshiki S, Hirokawa K. Osteopontin mRNA is expressed by smooth muscle-derived foam cells in human atherosclerotic lesions of the aorta. J Clin Invest. 1993;92(6):2814-20.

10. Koshikawa M, Aizawa K, Kasai H, Izawa A, Tomita T, Kumazaki S, et al. Elevated osteopontin levels in patients with peripheral arterial disease. Angiology. 2009;60(1):42-5.

11. Smith AD, Schoenhagen P. CT imaging for acute aortic syndrome. Cleve Clin J Med. 2008;75(1):7-9, 12, 15-7.

12. Singh M, Ananthula S, Milhorn DM, Krishnaswamy G, Singh K. Osteopontin: a novel inflammatory mediator of cardiovascular disease. Front Biosci. 2007;12:214-21.
13. Xie Z, Singh M, Singh K. Osteopontin modulates myocardial hypertrophy in response to chronic pressure overload in mice. Hypertension. 2004;44(6):826-31.

14. Sodhi CP, Phadke SA, Batlle D, Sahai A. Hypoxia and high glucose cause exaggerated mesangial cell growth and collagen synthesis: role of osteopontin. Am J Physiol Renal Physiol. 2001;280(4):F667-74.

15. Ashizawa N, Graf K, Do YS, Nunohiro T, Giachelli CM, Meehan WP, et al. Osteopontin is produced by rat cardiac fibroblasts and mediates A(II)-induced DNA synthesis and collagen gel contraction. J Clin Invest. 1996;98(10):2218-27.

16. Xie Z, Singh M, Siwik DA, Joyner WL, Singh K. Osteopontin inhibits interleukin- $1 \beta$-stimulated increases in matrix metalloproteinase activity in adult rat cardiac fibroblasts: role of protein kinase $\mathrm{C}-\zeta$. J Biol Chem. 2003;278(49):48546-52.

17. Isoda K, Nishikawa K, Kamezawa Y, Yoshida M, Kusuhara M, Moroi M, et al. Osteopontin plays an important role in the development of medial thickening and neointimal formation. Circ Res. 2002;91(1):77-82.

18. Chiba S, Okamoto H, Kon S, Kimura C, Murakami M, Inobe $\mathrm{M}$, et al. Development of atherosclerosis in osteopontin transgenic mice. Heart Vessels. 2002;16(3):111-7.

19. Georgiadou P, Iliodromitis EK, Kolokathis F, Mavroidis M, Andreadou I, Demopoulou M, et al. Plasma levels of osteopontin before and $24 \mathrm{~h}$ after percutaneous coronary intervention. Expert Opin Ther Targets. 2008;12(12):1477-80.

20. Okamoto H. Osteopontin and cardiovascular system. Mol Cell Biochem. 2007;300(1-2):1-7.

21. Golledge J, Muller J, Shephard N, Clancy P, Smallwood L, Moran C, et al. Association between osteopontin and human abdominal aortic aneurysm. Arterioscler Thromb Vasc Biol. 2007;27(3):655-60.

22. Ohmori R, Momiyama Y, Taniguchi H, Takahashi R, Kusuhara M, Nakamura H, et al. Plasma osteopontin levels are associated with the presence and extent of coronary artery disease. Atherosclerosis. 2003;170(2):333-7.

23. Kato R, Momiyama Y, Ohmori R, Tanaka N, Taniguchi H, Arakawa K, et al. High plasma levels of osteopontin in patients with restenosis after percutaneous coronary intervention. Arterioscler Thromb Vasc Biol. 2006;26(1):e1-2.

24. Giachelli CM, Bae N, Almeida M, Denhardt DT, Alpers CE, Schwartz SM. Osteopontin is elevated during neointima formation in rat arteries and is a novel component of human atherosclerotic plaques. J Clin Invest. 1993;92(4):1686-96.

25. Gadeau AP, Chaulet H, Daret D, Kockx M, Daniel-Lamazière JM, Desgranges C. Time course of osteopontin, osteocalcin, 
and osteonectin accumulation and calcification after acute vessel wall injury. J Histochem Cytochem. 2001;49(1):79-86.

26. Lesauskaite V, Tanganelli P, Sassi C, Neri E, Diciolla F, Ivanoviene L, et al. Smooth muscle cells of the media in the dilatative pathology of ascending thoracic aorta: morphology, immunoreactivity for osteopontin, matrix metalloproteinases, and their inhibitors. Hum Pathol. 2001;32(9):1003-11.

27. Liaw L, Lindner V, Schwartz SM, Chambers AF, Giachelli $\mathrm{CM}$. Osteopontin and $\beta_{3}$ integrin are coordinately expressed in regenerating endothelium in vivo and stimulate Arg-Gly-
Asp-dependent endothelial migration in vitro. Circ Res. 1995;77(4):665-72.

28. Ström A, Franzén A, Wängnerud C, Knutsson AK, Heinegård D, Hultgårdh-Nilsson A. Altered vascular remodeling in osteopontin-deficient atherosclerotic mice. J Vasc Res. 2004;41(4):314-22.

29. Takemoto M, Yokote K, Nishimura M, Shigematsu T, Hasegawa T, Kon S, et al. Enhanced expression of osteopontin in human diabetic artery and analysis of its functional role in accelerated atherogenesis. Arterioscler Thromb Vasc Biol. 2000;20(3):624-8. 